\title{
Cardiac biomarkers and blood metabolites in cows with clinical ketosis
}

\section{Biomarcadores cardíacos e metabólitos sanguíneos em vacas com cetose clínica}

\author{
Gliére Silmara Leite Soares ${ }^{1 *}$; Ana Clara Sarzedas Ribeiro ${ }^{2}$; Jobson Filipe de Paula \\ Cajueiro $^{3}$; Rodolfo José Cavalcanti Souto ${ }^{3}$; Emanuel Felipe de Oliveira Filho'; \\ Pierre Castro Soares ${ }^{4}$; Carla Lopes de Mendonça ${ }^{3}$; José Augusto Bastos Afonso ${ }^{3}$
}

\begin{abstract}
The increase in energy imbalance at the beginning of lactation leads to metabolic disorders, especially clinical ketosis, in highly productive dairy cows. The objective of this study is to evaluate the clinical characteristics, biochemical parameters, and cardiac biomarkers creatine kinase MB isoenzyme (CK$\mathrm{MB}$ ) and cardiac troponin I (cTnI) of 15 cows diagnosed with clinical ketosis treated at the Bovine Clinic of Garanhuns at the Federal Rural University of Pernambuco. Nine of the 15 cows were diagnosed with primary ketosis and six had concomitant diseases, including left abomasal displacement, metritis, pneumonia, and renal failure. The observed clinical signs were non-specific and included decreased appetite and milk production and weight loss. Approximately $53 \%$ of the animals had central nervous system involvement. For biochemical evaluation, 15 high-production healthy dairy cows at the initial stage of lactation served as the control group. The data were subjected to analysis of variance for simultaneous comparison between two means allowing testing the hypothesis on the means of the different groups and subjected to Pearson correlation at a level of significance of $5 \%$. The levels of $\beta$-hydroxybutyrate (BHB), non-esterified fatty acids (NEFA), glucose, fructosamine, total protein, albumin, creatinine, aspartate aminotransferase, creatine kinase, CK-MB, and cTnI were higher in the group with ketosis. The diseased animals presented changes in glycemia, reduction in tissue sensitivity to insulin, and a lower RQUICKI-BHB index, especially hyperglycemic animals. The increase in the levels of cardiac biomarkers suggests the occurrence of myocardial injury associated with bovine ketosis.
\end{abstract}

Key words: Non-esterified fatty acids. $\beta$-hydroxybutyrate. Creatine kinase MB. Insulin sensitivity. Cardiac troponin I.

\footnotetext{
1 Discentes, Curso de Doutorado, Programa de Pós-Graduação em Medicina Veterinária, Universidade Federal Rural de Pernambuco, UFRPE, Recife, PE, Brasil. E-mail: glieresoares87@gmail.com; felipe130188@gmail.com

2 Discente, Curso de Mestrado, Programa de Pós-Graduação em Sanidade e Reprodução de Ruminantes, Universidade Federal Rural de Pernambuco/Unidade Acadêmica de Garanhuns, UFRPE/UAG, Garanhuns, PE, Brasil. E-mail: aninhahsarzedas@ hotmail.com

3 Médicos Veterinários, Clínica de Bovinos de Garanhuns, campus Garanhuns/UFRPE, CBG/UFRPE, Garanhuns, PE, Brasil. E-mail: jobson.filipe@gmail.com; rodolfojcsouto@gmail.com; carlalopes.mendonca@gmail.com; afonsojab@oi.com.br

4 Prof., Pesquisador, Departamento de Medicina Veterinária, Universidade Federal Rural de Pernambuco, DMV/UFRPE, Recife, PE, Brasil. E-mail: pcastro.pe@gmail.com

* Author for correpondence
} 


\section{Resumo}

A intensificação do desequilíbrio energético no início da lactação é responsável pelo surgimento de distúrbios metabólicos em vacas de alta produção leiteira, em especial a cetose clínica. Este trabalho objetivou estudar o comportamento clínico, os parâmetros bioquímicos e os biomarcadores cardíacos, isoenzima MB da creatina quinase (CK-MB) e troponina cardíaca I (cTnI), de 15 vacas diagnosticadas com cetose clínica, atendidas na Clínica de Bovinos de Garanhuns, Campus da Universidade Federal Rural de Pernambuco. Nove dessas 15 vacas foram diagnosticadas com cetose primária e seis apresentaram doenças concomitantes como, deslocamento de abomaso à esquerda, metrite, pneumonia e insuficiência renal. Os sinais clínicos observados foram inespecíficos, tais como diminuição do apetite, da produção de leite e do peso. Aproximadamente 53\% dos animais apresentaram sintomatologia nervosa. Para avaliação bioquímica foi selecionado um grupo de 15 vacas de alta produção, sadias e em estágio inicial de lactação, para compor o grupo controle. Os dados foram submetidos à análise de variância para comparação simultânea entre duas médias, permitindo testar a hipótese sobre as médias dos distintos grupos, além de correlações de Pearson, ao nível de $5 \%$ de probabilidade. As variáveis, $\beta$-Hidroxibutirato (BHB), ácidos graxos não esterificados (AGNEs), glicose, frutosamina, proteína total, albumina, creatinina, aspartato aminotransferase, creatina quinase, CK-MB e cTnI apresentaramse mais elevadas no grupo de animais cetóticos. Os animais doentes apresentaram variação no estado glicêmico e redução da sensibilidade dos tecidos à insulina, com menor valor do índice RQUICKI$\mathrm{BHB}$, principalmente aqueles animais hiperglicêmicos. A elevação dos biomarcadores cardíacos sugere a ocorrência de lesão miocárdica associada à cetose bovina.

Palavras-chave: Ácidos graxos não esterificados. $\beta$-Hidroxibutirato. Creatina quinase MB. Sensibilidade à insulina. Troponina cardíaca I.

\section{Introduction}

Ketosis is a metabolic disease that affects high milk production female bovines and buffaloes and is caused by the imbalance in carbohydrate metabolism due to the high energy demand generated in the transition period (ASRAT et al., 2013; BISWAL et al., 2016; KUMAR et al., 2015).

The increase in energy demand for fetal development at the end of gestation and for milk production at the beginning of lactation, associated with the inability to meet this demand through diet, causes negative energy balance (NEB). When exacerbated, this condition may result in pathological metabolic conditions, including decreased glycemic index and consequent hyperketonemia (CONSTABLE et al., 2017). The blood metabolites $\beta$-hydroxybutyrate (BHB) and non-esterified fatty acids (NEFA) are considered good biochemical indicators of the development of metabolic diseases common in the transition period (MCART et al., 2013). Studies correlated different concentrations of these metabolites with disease outcomes and demonstrated that serum concentrations $\geq 1.2$ mmol L-1 of BHB and $\geq 1.0 \mathrm{mmol} \mathrm{L}^{-1}$ of NEFA at the beginning of lactation increased the likelihood of developing clinical ketosis and other diseases common in this period (CHAPINAL et al., 2011; DUFFIELD et al., 2009; SEIFI et al., 2011).

Bovine ketosis causes substantial economic losses to dairy cattle production by decreasing milk production, increasing the cost of treatment of diseased animals, increasing the risk of other diseases, and potentially resulting in the early slaughter of these animals (BISWAL et al., 2016; GORDON et al., 2013).

The prevalence of clinical ketosis varies between 8.4\% and 27.2\% in Asian dairy herds (ASRAT et al., 2013; BISWAL et al., 2016; DAR et al., 2017; ŞENTÜRK et al., 2016) and between $0.4 \%$ and $11.1 \%$ in European herds (SUTHAR et al., 2013). These rates are much lower than those found for the subclinical form of the disease (40-80\%) in a herd (MCART et al., 2013). Cows can be affected at any age in the production phase. Nonetheless, studies 
indicate that the prevalence is highest in the third or fourth lactation and that most cases occur during the first month after calving (ASRAT et al., 2013; BISWAL et al., 2016; CONSTABLE et al., 2017; DAR et al., 2017). Risk factors such as number of lactations, high body condition score, number of days of lactation, and high milk production are significantly correlated with the development of bovine ketosis (DAR et al., 2017; RASMUSSENT et al., 1999; VANHOLDER et al., 2015).

Clinically, ketosis is characterized by increased concentrations of ketone bodies in the blood, urine, and milk combined with clinical signs such as inappetence, reduction in milk production, weight loss, and dry feces (GORDON et al., 2013). Some animals may present the nervous form of the disease, with neurological signs and abnormal behaviors, including walking in circles, head pressing, loss of balance, loss of visual acuity, depraved appetite, empty mastication with drooling, hyperesthesia, and tremors (CONSTABLE et al., 2017).

Studies measured blood biomarkers, including creatine kinase $\mathrm{MB}$ isoenzyme (CK-MB) and cardiac troponin I (cTnI), which are indicators of myocardial injury in humans and animals, and showed that animals with hyperketonemia had cardiac involvement (GEREDE et al., 2016; SOUZA et al., 2018; THARWAT et al., 2012). Other studies found that the serum levels of these biomarkers were increased in cows diagnosed with different diseases that are common in the peripartum period, and these levels affect prognosis (BASBUGAN et al., 2015; VARGA et al., 2013).

Therefore, in view of the relevance of ketosis to the health of cattle and the scarcity of information about clinical bovine ketosis in Brazil, the objective of this study is to present clinical, epidemiological, and laboratory characteristics of this disease, with particular emphasis on cardiac biomarkers (CK$\mathrm{MB}$ and $\mathrm{cTnI}$ ) because these markers have not been correlated with this disease to date.

\section{Materials and Methods}

This study evaluated 15 dairy cows diagnosed with clinical ketosis originated from farms located in several municipalities of Pernambuco and treated at the Bovine Clinic of Garanhuns at the Federal Rural University of Pernambuco.

All animals underwent clinical examination according to the recommendations of Dirksen et al. (1993). Blood samples were collected by jugular venipuncture to determine the serum concentration of BHB ( $\beta \mathrm{HB} /$ Rambut, RANDOX Laboratories Ltd., UK), and animals with clinical signs and $\mathrm{BHB}$ concentration $\geq 1.2 \mathrm{mmol} \mathrm{L}^{-1}$ were considered positive (SEIFI et al., 2011; MCART et al., 2013; CONSTABLE et al., 2017). Urine samples were collected by spontaneous micturition for semiquantitative determination of ketone bodies using reagent strips (UriAction 10, Labtest Diagnóstica S.A., Brazil).

Other analyzed blood metabolites were non-esterified fatty acids (NEFA, RANDOX Laboratories Ltd., UK), total protein (Proteínas Totais, Labtest Diagnóstica S.A., Brazil), albumin (Albumina, Labtest Diagnóstica S.A., Brazil), aspartate aminotransferase (AST/GOT Liquiform, Labtest Diagnóstica S.A., Brazil), gammaglutamyltransferase (Gama GT Liquiform, Labtest Diagnóstica S.A, Brazil), creatine kinase (CKNAC Liquiform, Labtest Diagnóstica S.A., Brazil), fructosamine (Frutosamina, Labtest Diagnóstica S.A., Brazil), total calcium (Cálcio Liquiform, Labtest Diagnóstica S.A., Brazil), and glucose glicose (Glicose Liquiform, Labtest Diagnóstica S.A., Brazil) in a semiautomatic biochemical analyzer (BIO 2000, Bioplus Produtos Para Laboratórios Ltda., Brazil). The serum activity of CK-MB (CK-MB Liquiform, Labtest Diagnóstica S.A., Brazil) was determined in an automatic biochemical analyzer (Labmax 240 Premium, Labtest Diagnóstica S.A., Brazil). The serum concentrations of cTnI, insulin, and cortisol were determined by chemiluminescent immunoassay 
using commercial kits (Access Immunoassay Systems, Beckman Coulter, USA).

Insulin sensitivity was estimated using the Revised Quantitative Insulin Sensitivity Check Index (RQUICKI) and RQUICKI-BHB, which takes into account the concentration of glucose, insulin, NEFA, and BHB according to the following equations: RQUICKI=1/[log10 (glucose, $\mathrm{mg} \mathrm{dL}^{-1}$ ) $+\log 10$ (insulin, $\mu \mathrm{U} \mathrm{mL}^{-1}$ ) $+\log 10$ (NEFA, mmol $\left.\left.\mathrm{L}^{-1}\right)\right]$; and RQUICKI-BHB $=1 /[\log 10$ (glucose, mg $\left.\mathrm{dL}^{-1}\right)+\log 10$ (insulin, $\mu \mathrm{U} \mathrm{mL}^{-1}$ ) $+\log 10$ (NEFA, mmol L-1) $\left.+\log 10\left(\mathrm{BHB}, \mathrm{mmol} \mathrm{L}^{-1}\right)\right]$ (DJOKOVIĆ et al., 2017; HOLTENIUS; HOLTENIUS, 2007).

For statistical analysis, a control group $(\mathrm{n}=15)$ comprised cows with productive characteristics similar to those of the ketotic group, including high yield, Girolanda breed with genetic composition of 3/4 Holstein and 5/8 Girolanda, initial stage of lactation (10 days after calving), and body condition score between 3.0 and 3.5. All animals were reared in a semi-intensive management system. The normal distribution of the data set was initially analyzed using the KolmogorovSmirnov test. After that, the variables that did not satisfy the normality assumption were subjected to the logarithmic transformation or the square root of $x+1$. The data with normal distribution were transformed and subjected to analysis of variance for simultaneous comparison between two means, and the hypothesis on the means of different groups was tested using MINITAB $^{\circledR}$ software version 18. A level of significance of $5 \%$ was used in all analyses. Correlations between pairs of variables were estimated using the Pearson coefficient, and the significance obtained in the linear correlation was evaluated according to Little and Hills (1978).

\section{Results}

The age of the ketotic animals varied from 3.5 to 9.0 years, with a mean of 5.5 years. Most of the animals were crossbred obtained by the crossing of dairy breeds (Holstein and Girolanda) and were kept in a semi-intensive management system. All diseased cows were multiparous, with a mean of three calvings, and were at the initial phase of lactation, with a mean of 19 days after calving. Eleven of the 15 cases occurred during the dry season in the region, between October and March. Concomitant diseases were diagnosed in six animals, including left abomasal displacement $(\mathrm{n}=2)$, metritis $(\mathrm{n}=$ $2)$, pneumonia $(n=1)$, and renal failure $(n=1)$. The mean period of clinical evolution was 14 days, counting from the observation of the clinical signs by farmers until clinical resolution, and was longer in the animals with concomitant diseases. With respect to clinical resolution, $93.3 \%(14 / 15)$ of the animals were discharged after treatment, and $6.7 \%$ $(1 / 15)$ died.

The main changes reported in anamnesis were decreased appetite, lower milk production, weight loss, and neurological changes, including staggering gait and depraved appetite. The results of the physical examination indicated that most of the animals were in the standing positionand alert, with mild to moderate dehydration. Moreover, vital parameters, including heart rate, respiratory rate, and rectal temperature, were within the physiological range for the species (Table 1). Ruminal motility was decreased in most animals. However, the feces were normal. The mean body condition score of the animals was $3.0 \pm 0.7$, and the score for most animals was equal to or higher than the mean. It is worth noting that neurological changes occurred in 53.3\% of the animals, including motor incoordination, muscle tremor, depraved appetite, teeth grinding, vocalization, salivation, and agitated or aggressive behavior.

The mean BHB concentration was $3.01 \mathrm{mmol}$ $\mathrm{L}^{-1}$, and ketone bodies were present in the urine of all affected animals. The concentration of the cardiac biomarkers CK-MB and cTnI was significantly higher $(\mathrm{p}<0.05)$ in the ketotic group than in the control group. The concentration of other biochemical markers was comparatively higher in the ketosis group, except for cortisol, insulin, 
globulin, GGT, and total calcium, whose levels observed in this group (Table 3). The analysis of were similar $(p>0.05$ ) between the groups (Table 2$)$. insulin sensitivity using RQUICKI and RQUICKIThe mean glucose concentration was comparatively BHB indicated that only RQUICKI-BHB was higher in the ketotic group; however, hypoglycemic, significantly lower $(\mathrm{p}<0.0001)$ in the animals with normoglycemic, and hyperglycemic cows were clinical ketosis.

Table 1. Absolute and relative frequencies of clinical signs in cows diagnosed with clinical ketosis $(\mathrm{n}=15)$.

\begin{tabular}{|c|c|c|c|}
\hline \multirow{2}{*}{ Characteristics } & \multirow{2}{*}{ Clinical signs } & \multicolumn{2}{|c|}{ Number of animals } \\
\hline & & $\mathrm{AF}^{*}$ & $\mathrm{RF}^{* *}(\%)$ \\
\hline \multirow[t]{2}{*}{ Posture } & Standing & 14 & 93.335 \\
\hline & Recumbency & 1 & 6.66 \\
\hline \multirow[t]{4}{*}{ Appetite } & Present & 10 & 66.66 \\
\hline & Absent & 2 & 13.33 \\
\hline & Capricious & 2 & 13.33 \\
\hline & Not reported & 1 & 6.66 \\
\hline \multirow[t]{4}{*}{ Behavior } & Active & 1 & 6.66 \\
\hline & Agitated & 2 & 13.33 \\
\hline & Calm & 9 & 60.0 \\
\hline & Apathetic & 3 & 20.0 \\
\hline \multirow[t]{2}{*}{ Neurological signs } & Present & 8 & 53.33 \\
\hline & Absent & 7 & 46.66 \\
\hline \multirow[t]{2}{*}{ Temperature } & Normal $\left(37.0-39.5^{\circ} \mathrm{C}\right)$ & 13 & 86.66 \\
\hline & $\operatorname{High}\left(>39.5^{\circ} \mathrm{C}\right)$ & 2 & 13.33 \\
\hline \multirow[t]{3}{*}{ Dehydration } & Absent & 2 & 13.33 \\
\hline & Mild & 8 & 53.33 \\
\hline & Moderate & 5 & 33.33 \\
\hline \multirow[t]{2}{*}{ HR (bpm) } & Normal (60-80) & 12 & 80.0 \\
\hline & $\operatorname{High}(>80)$ & 3 & 20.0 \\
\hline \multirow[t]{3}{*}{ RR (mrpm) } & Normal (24-36) & 8 & 53.33 \\
\hline & Low $(<24)$ & 3 & 20.0 \\
\hline & $\operatorname{High}(>36)$ & 4 & 26.66 \\
\hline \multirow[t]{4}{*}{ Rumen motility } & Absent & 2 & 13.33 \\
\hline & Physiological & 4 & 26.66 \\
\hline & Increased & 1 & 6.66 \\
\hline & Decreased & 8 & 53.33 \\
\hline \multirow[t]{3}{*}{ Feces } & Physiological & 9 & 60.0 \\
\hline & Scanty & 4 & 26.66 \\
\hline & Not reported & 2 & 13.33 \\
\hline
\end{tabular}

*AF, absolute frequency; $* * \mathrm{RF}$, relative frequency. 
The following associations were found in the $\mathrm{p}<0.0001), \mathrm{CK} \times \mathrm{CK}-\mathrm{MB}(\mathrm{r}=0.53 ; \mathrm{p}=0.003)$, insulin correlation analysis: NEFA $\times$ BHB $(r=0.437 ; \quad \times$ glucose $(r=0.45 ; \mathrm{p}=0.016)$, and RQUICKI-BHB $\times$ $\mathrm{p}=0.016), \mathrm{BHB} \times \mathrm{CK}-\mathrm{MB}(\mathrm{r}=0.47 ; \mathrm{p}=0.009), \mathrm{BHB} \quad \mathrm{cTnI}(\mathrm{r}=-0.38 ; \mathrm{p}=0.05)$.

$\times$ cTnI $(r=0.41 ; p=0.027), c T n I \times C K(r=0.63 ;$

Table 2. Means, standard error of the mean, and level of significance of biochemical markers, hormonal markers, and myocardial activity of cows with $(n=15)$ and without $(n=15)$ clinical ketosis.

\begin{tabular}{lcccc}
\hline Variables & Unit & Healthy cows & Ketotic cows & p-value \\
BHB & $\left(\mathrm{mmol} \mathrm{L}^{-1}\right)$ & $0.34 \pm 0.03^{\mathrm{B}}$ & $3.01 \pm 0.42^{\mathrm{A}}$ & $<0.0001$ \\
NEFA & $\left(\mathrm{mmol} \mathrm{L}^{-1}\right)$ & $0.71 \pm 0.16^{\mathrm{B}}$ & $1.48 \pm 0.15^{\mathrm{A}}$ & 0.0002 \\
Glucose & $\left(\mathrm{mg} \mathrm{dL}^{-1}\right)$ & $45.50 \pm 1.44^{\mathrm{B}}$ & $75.70 \pm 11.0^{\mathrm{A}}$ & 0.0073 \\
Fructosamine & $\left(\mu \mathrm{mol} \mathrm{L}^{-1}\right)$ & $180.53 \pm 5.73^{\mathrm{B}}$ & $278.6 \pm 21.2^{\mathrm{A}}$ & $<0.0001$ \\
Cortisol & $\left(\mathrm{nmol} \mathrm{L}^{-1}\right)$ & $44.99 \pm 9.57$ & $80.0 \pm 19.6$ & 0.1799 \\
Insulin & $\left(\mathrm{pmol} \mathrm{L}^{-1}\right)$ & $5.07 \pm 0.56$ & $3.93 \pm 0.92$ & 0.2973 \\
RQUICKI* & & $0.95 \pm 0.09$ & $0.76 \pm 0.09$ & 0.1098 \\
RQUICKI-BHB & & $1.94 \pm 0.29^{\mathrm{A}}$ & $0.56 \pm 0.05^{\mathrm{B}}$ & $<0.0001$ \\
Total calcium & $\left(\mathrm{mg} \mathrm{dL}^{-1}\right)$ & $8.47 \pm 0.30$ & $8.33 \pm 0.23$ & 0.7271 \\
Total protein & $\left(\mathrm{g} \mathrm{dL}^{-1}\right)$ & $7.16 \pm 0.19^{\mathrm{B}}$ & $7.76 \pm 0.20^{\mathrm{A}}$ & 0.0392 \\
Albumin & $\left(\mathrm{g} \mathrm{dL}^{-1}\right)$ & $2.58 \pm 0.06^{\mathrm{B}}$ & $2.92 \pm 0.08^{\mathrm{A}}$ & 0.0034 \\
Globulin & $\left(\mathrm{g} \mathrm{dL}^{-1}\right)$ & $4.58 \pm 0.19$ & $4.84 \pm 0.17$ & 0.3121 \\
A/G ratio & & $0.58 \pm 0.03$ & $0.61 \pm 0.03$ & 0.4357 \\
Creatinine & $\left(\mathrm{mg} \mathrm{dL}^{-1}\right)$ & $0.7 \pm 0.5^{\mathrm{B}}$ & $1.3 \pm 0.22^{\mathrm{A}}$ & 0.0013 \\
AST & $\left(\mathrm{U} \mathrm{L}^{-1}\right)$ & $60.1 \pm 3.7^{\mathrm{B}}$ & $163 . \pm 34 .^{\mathrm{A}}$ & $<0.0001$ \\
GGT & $\left(\mathrm{U} \mathrm{L}^{-1}\right)$ & $27.54 \pm 1.64$ & $31.62 \pm 3.07$ & 0.5549 \\
CK & $\left(\mathrm{U} \mathrm{L}^{-1}\right)$ & $68 . \pm 7.3^{\mathrm{B}}$ & $1344.0 \pm 402.0^{\mathrm{A}}$ & $<0.0001$ \\
CK-MB & $\left(\mathrm{ng} \mathrm{mL}^{-1}\right)$ & $86.0 \pm 13.6^{\mathrm{B}}$ & $211.5 \pm 43.7^{\mathrm{A}}$ & 0.0157 \\
cTnI & $\left(\mathrm{ng} \mathrm{mL}^{-1}\right)$ & $0.02 \pm 0.00^{\mathrm{B}}$ & $0.07 \pm 0.03^{\mathrm{A}}$ & 0.0284 \\
\hline
\end{tabular}

*Revised Quantitative Insulin Sensitivity Check Index.

Table 3. Means and standard error of the mean of glucose levels and insulin sensitivity index in cows with clinical ketosis.

\begin{tabular}{lcccc}
\hline \multicolumn{1}{c}{ Glycemic status } & Number of animals & $\begin{array}{c}\text { Glucose } \\
\left(\mathbf{m g ~ d L}^{-1}\right)\end{array}$ & RQUICKI & RQUICKI-BHB \\
\hline Hypoglycemia & $4(26.6 \%)$ & $37.98 \pm 2.01$ & $1.10 \pm 0.10$ & $0.72 \pm 0.06$ \\
Normoglycemia & $6(40 \%)$ & $61.86 \pm 3.61$ & $0.77 \pm 0.10$ & $0.63 \pm 0.07$ \\
Hyperglycemia & $5(33.3 \%)$ & $116.82 \pm 13.63$ & $0.46 \pm 0.03$ & $0.39 \pm 0.03$ \\
\hline
\end{tabular}

\section{Discussion}

The occurrence of clinical ketosis singly and the occasional association of this disease with other diseases corroborate the results of other studies, which classified ketosis as primary in cases in which disease was a result of the inability of the adaptive mechanisms to meet the high energy demand, or secondary in cases in which the presence of 
concomitant diseases usually resulted in decreased food intake and might cause disease (BALI et al., 2016; CONSTABLE et al., 2017; VAJA et al., 2016).

The occurrence of clinical ketosis in dairy cows with the breed characteristics found in this study is directly related to the composition of the herds of the region, characterized by the predominance of highyield cows originated from the crossing of dairy breeds (Girolanda, Holstein, and their crosses). Biswal et al. (2016) found that the prevalence of ketosis was higher in crossbred animals of the Jersey and Holstein breeds when compared to animals of local breeds in India, possibly because of the composition of the herds in the studied region.

The predominance of semi-intensive management systems and the higher disease prevalence during the dry season are related to the food management system adopted by the farmers because the irregularity of the rains in the region leads to the irregular availability of dietary constituents such as fodder and grains, causing farmers to alternate the diet formulations. Dar et al. (2017) evaluated the effect of seasonality on the development of ketosis and observed that disease prevalence was higher in the dry season because of the lower availability or lack of high-quality forage in this period. Allen and Piantoni (2013) reported that dietary supplementation with concentrate in the dry season, which is common in the analyzed region, might favor excessive weight gain, increasing the risk of developing ketosis. Vanholder et al. (2015) corroborated these results and reported that the likelihood of developing ketosis was 3.6 and 8.7fold higher in animals with moderate or high body condition score.

Asrat et al. (2013), Biswal et al. (2016), and Dar et al. (2017) indicated that the prevalence of clinical ketosis was comparatively higher in the first month of lactation, as observed in the present study. Metabolic demand is higher in this phase, and the energy imbalance associated with lower dry matter consumption might explain the higher disease prevalence (DAR et al., 2017; MCART et al., 2013).

Cows of any age in the productive phase can develop ketosis. In this study, the disease predominated in animals aged approximately 5 years, with a mean of three calvings. However, studies have shown that the prevalence of clinical ketosis increases with age, and the number of calvings is higher in the fourth lactation (ASRAT et al., 2013; BISWAL et al., 2016). Dairy cows produce a higher volume of milk between the third and fifth lactations because the mammary glands are fully mature at this phase. Therefore, this production phase increases the metabolic challenges in the animals, which develop diseases when these challenges are not met by the adaptive mechanisms (BISWAL et al., 2016). In this respect, Vanholder et al. (2015) observed that cows with three or more calvings were 2.2 times more likely to be affected by clinical ketosis.

The clinical signs of ketosis are non-specific, including decreased appetite, lower milk production, and weight loss, and are common in other diseases such as disorders of the digestive tract (CÂMARA et al., 2009, 2010; OETZEL, 2007; SILVA FILHO et al., 2012). These clinical signs were also reported by Issi et al. (2016) and Şentürk et al. (2016) in cows, and by Bali et al. (2016) in buffaloes with ketosis. NEFA are released in the bloodstream in the lipolytic phase, and these substances are precursors of ketone bodies and serve as energy sources. However, the complete oxidation of NEFA in hepatocytes compromises the feeding behavior of the animals by causing satiety (ALLEN; PIANTONI, 2013). Furthermore, the reduced capacity of the animal to produce lactogenic precursors through the diet because of the lower intake of dry matter combined with high BEN contributes to the lower milk production in this period (BALI et al., 2016).

The normality of vital parameters combined with lower ruminal motility was also reported by Issi et al. (2016) and Vaja et al. (2016). However, these authors observed the presence of dry feces 
and ketotic breath, which were not observed in the present study.

The percentage of animals with central nervous system involvement (53.3\%) in our study was much higher than that reported by Lean (2002) in cows $(10 \%)$ and by Bali et al. (2016) in buffaloes $(6 \%)$. Other studies reported the development of nervous ketosis in cows (WOOTTON, 1992; REDDY et al., 2014) and buffaloes (UPADHYAY et al., 2007) and associated the presence of neurological changes with the increased production of isopropyl alcohol and changes in the serum levels of BHB and glucose, which are common in ketosis. However, nervous symptoms are not present in all ketosis animals or in those with similar metabolic conditions, such as animals with inappetence, suggesting the occurrence of individual variations in the susceptibility to metabolic changes that induce nervous manifestations (FOSTER, 1988; CONSTABLE et al., 2017). Sato (2009) corroborated this finding and observed that there was a significant increase in isopropanol concentrations in ketotic cows without manifestation of neurological signs.

The magnitude of the increase in the concentrations of BHB and NEFA consistently characterized the clinical condition of ketotic animals, and this finding was supported by the moderate correlation between these variables in our study. This result agrees with the study by Djoković et al. (2014) and Xu et al. (2014) in dairy cows with ketosis. Some studies have shown that the blood concentration of BHB is above $2.6 \mathrm{mmol} \mathrm{L}^{-1}$ (ISSSI et al., 2016; MARUTSOVA; MARUTSOV, 2016) or $3.0 \mathrm{mmol} \mathrm{L}^{-1}$ (OETZEL, 2007) in animals with clinical ketosis. However, it should be emphasized that the blood concentrations of this metabolite may vary on an individual basis (İSSİ et al., 2016; MARUTSOVA; MARUTSOV, 2016; SAHINDURAN et al., 2010; ŞENTÜRK et al., 2016), as verified in our sample, in which the concentration varied from $1.4 \mathrm{mmol} \mathrm{L}^{-1}$ to $6.7 \mathrm{mmol}$ $\mathrm{L}^{-1}$. In addition, animals with serum concentrations $\geq 1.2 \mathrm{mmol} \mathrm{L}^{-1}$ of BHB and $1.0 \mathrm{mmol} \mathrm{L}^{-1}$ of NEFA at early lactation are more likely to develop clinical ketosis (SEIFI et al., 2011).

Clinical ketosis is characterized by hyperketonemia and ketonuria, which were observed in all affected animals, as well as clinical signs (CONSTABLE et al., 2017). NEFA and BHB are products of adipose tissue catabolism and act as alternative energy sources in tissues. However, the high concentrations of these metabolites in the blood reflect the degree of energy imbalance in the animals (DRACKLEY et al., 2005). The increased $\beta$-oxidation of NEFA in the liver may cause complications, including decreased appetite, inhibition of immune function, and loss of the balance between oxidant and antioxidant systems, generating oxidative stress (ALLEN; PIANTONI, 2013; SORDILLO; WILLIAM, 2013; XU et al., 2014).

The mean blood glucose concentration in the ketotic group was significantly higher than in the control group and was at the upper normal range (KANEKO, 2008). However, the affected animals had changes in glycemia, including hypoglycemia $(n=4)$, normoglycemia $(n=6)$, and hyperglycemia $(\mathrm{n}=5)$, and these conditions were also observed in sheep (HENZE et al., 1998; SANTOS et al., 2011) and goats (SOUTO et al., 2013) with pregnancy toxemia. Nonetheless, this condition was not observed in other studies with cows, and most of these studies indicated that the development of clinical hypoglycemia was justified by the high demand of glucose for the synthesis of milk lactose (ELITOK et al., 2010; İSSİ et al., 2016; SAHINDURAN et al., 2010; ŞENTÜRK et al., 2016; XU et al., 2014).

In some cases, the hyperglycemic state may be explained by the increase in serum cortisol concentrations induced by stress due to $\mathrm{BEN}$ in the transition period (CHALMEH; HAJIMOHAMMADI, 2016). A similar condition was observed in the present study. Despite the absence of significant differences in cortisol 
concentrations, the mean concentration of this hormone was higher in ketotic animals, potentially resulting in the glycemic status in these animals, as reported previously (SIMONOV; VLIZLO, 2013). In contrast, Djoković et al. (2014), Forslund et al. (2010), and Sahinduran et al. (2010) found that cortisol concentrations were comparatively lower in animals with clinical ketosis, and this response may be related to the limited synthesis of this hormone in cases of high energy demand. Another metabolic condition considered a triggering factor for hyperglycemia is the decrease in serum insulin concentrations, which was observed in our sample. Despite the absence of significant differences between the groups, insulin concentrations were lower in ketotic animals. Hayirli (2006) and Koster and Opsomer (2013) have shown that low insulin concentrations exacerbate lipid mobilization and increase the plasma concentrations of NEFA, which in turn inhibit insulin-dependent glucose uptake in peripheral tissues by decreasing the expression of GLUT4, consequently reducing the sensitivity of these tissues to insulin. Another contributing factor is the relationship between the hypoinsulinemia and the ability of $\beta$-pancreatic cells to produce and release this hormone during hypoglycemia at disease onset (DJOKOVIĆ et al., 2009; 2014). Hypoinsulinemia is directly associated with the increase in serum concentrations of NEFA, suggesting that the reduced anabolic effect of insulin on lipid metabolism results in the exacerbated mobilization of NEFA from body stores. In this respect, Kerestes et al. (2009) reported that the function of $\beta$-pancreatic cells and the biological potency of insulin were impaired in cows with prolonged hyperketonemia.

Djoković et al. (2017) evaluated insulin sensitivity in cows and observed that only the mean RQUICKI-BHB value was lower in ketotic animals. In addition, these two indexes were lower (RQUICKI-BHB, 0.39; RQUICKI, 0.46) in hyperglycemic animals from the disease group $(\mathrm{n}=5)$, suggesting higher tissue resistance to insulin in these animals. The inclusion of BHB in the calculation of the insulin sensitivity index improves the accuracy of the formula in cattle and sheep because this index is obtained under fasting conditions to maintain the insulin: glucose ratio in this period, although fasting in these animal species is not feasible because the rumen is a large food reservoir (BALOGH et al., 2008; NASCIMENTO, 2018). Some studies recommend using these indexes in bovine in situations involving impaired metabolic homeostasis and indicate that these indexes are more sensitive in indicating insulin resistance when compared to the individual evaluation of glucose, insulin, or NEFA (HOLTENIUS; HOLTENIUS, 2007; STENGÄRDE et al., 2011; XU et al., 2014).

The higher mean concentration of fructosamine in the diseased group reflects the increase in glycemia in this group. In this study, the isolated hyperglycemic condition in someketotic animals was probably the main contributor to the characteristics of this variable. Fructosamine reflects the glycemic state for a longer period 1 to 3 weeks before disease development and fructosamine measurement is less variable than glucose measurement (ALLISON, 2015 b). In dairy cows, there is a correlation between fructosamine and glucose in conditions in which glycemia is higher than the reference value, and this substance is considered a useful glycemic marker in these conditions (SORONDO; CIRIO, 2009).

The total calcium levels at the minimum threshold of normality observed in both groups and the absence of statistical difference between these groups are because dairy cows usually experience some degree of hypocalcemia at the beginning of lactation because of the high secretion of this mineral in the colostrum and milk, and the degree of hypocalcemia depends on the integrity of homeostatic mechanisms (GOFF, 2014). Although none of the evaluated groups presented hypocalcemia in our sample, this condition may be present in ketotic animals because of a deficit in dry matter consumption (BALI et al., 2016; YAMEOGO et al., 2008). 
The concentrations of creatinine were higher in ketotic cows than in the control group but remained within the normal range. This increase can be explained by the mild to moderate dehydration observed in the diseased animals (İSSI et al., 2016; SIMONOV; VLIZLO, 2013). Hemoconcentration is also linked to the higher concentrations of protein and serum albumin in ketotic animals. However, hypoalbuminemia occurred in both groups, which may be justified by the transition period in which the animals were found. The serum albumin concentration is decreased in the first month after calving as a result of the expansion of the plasma volume for milk production, loss of the uterine lumen during uterine involution, negative acutephase response induced by inflammatory processes in diseases that occur in the perinatal and postnatal periods, and protein catabolism resulting from NEB (CONSTABLE et al., 2017; REIS et al., 2016).

The globulin concentration and the albumin: globulin (A/G) ratio were not significantly different between the groups, and the observed hyperglobulinemia may be due to the higher synthesis of acute-phase proteins and immunoglobulins (ALLISON, 2015a). Reis et al. (2016) and Saut et al. (2009) observed that positive acute-phase proteins increased significantly in dairy cows in diseases that occur in the perinatal and postnatal periods.

Our results indicated that the serum activity of AST was increased in ketotic animals, whereas the serum activity of GGT was similar between the groups. Shin et al. (2015) found that the serum activity of AST was higher in ketotic cows, whereas GGT activity was similar between the disease and control groups, which is consistent with our results. Although AST is not a liver-specific enzyme, its activity is often associated with fatty liver in dairy cows (CEBRA et al., 1997) and is considered a more accurate indicator of early hepatic lipidosis than GGT activity (GONZÁLEZ et al., 2011). The possibility of development of muscle injury should be considered in these animals because the serum activity of CK, a muscle-specific enzyme, and AST, which is also found in muscle, was increased (HOFFMANN; SOLTER, 2008). This increase can be attributed to the potential muscular damage related to calving in all animals as well as to intermittent recumbency, muscle tremors, and the intramuscular administration of injectable medications in ketotic cows.

No studies to date correlated the cardiac markers cTnI and CK-MB with ketosis in cattle. However, the increase in these markers in ketotic cows may be due to lipotoxicity and oxidative stress because hyperketonemia generates free radicals and impairs antioxidative function, as observed in cows with subclinical ketosis (KARIMI et al., 2015; JACOB, PAKKIRI, 2017), ewes with pregnancy toxemia (AL-QUDAH, 2011) and humans with diabetes (JAIN et al., 2006). Free radicals exert cytotoxic action by the peroxidation of membrane phospholipids, resulting in structural changes, increased membrane permeability, and cell death (LIMA; ABDALLA, 2001; EL-DEEB, 2015). In addition, the incorporation of fatty acids and formation of micelles in the plasma membrane of the myocardium destabilizes and disrupts the cell membranes, resulting in the extravasation of cardiac markers (GEREDE et al., 2016). Studies reported that cTnI significantly increased in goats (THARWAT et al., 2012) and sheep (SOUZA et al., 2018) with pregnancy toxemia, and this disease caused focal degenerative changes in contractile and conductive myocardial cells (TONTIS; ZWAHLEN, 1987). These findings are reinforced by the correlation between BHB and cardiac markers. In addition, the hyperglycemic state observed in our sample is responsible for oxidative stress, as reported in humans (ORMAZABAL et al., 2018). This result is confirmed by the moderate negative correlation between the RQUICKI-BHB and cTnI in this study.

\section{Conclusion}

Clinical ketosis was diagnosed in highproduction dairy cows and is more common in 
the dry period. This disease was characterized by the high frequency of clinical neurological signs, changes in glycemia, decreased tissue sensitivity to insulin with a stronger decrease in hyperglycemic animals indicated by the low RQUICKI-BHB index, and elevation of cTnI and CK-MB, suggesting some degree of myocardial injury. It is worth noting that the serum concentrations of these markers may serve as critical prognostic indicators in cattle with clinical ketosis; however, further studies are needed to support this hypothesis.

\section{Acknowledgments}

The authors are grateful to the Research Foundation of the State of Pernambuco (FACEPE) for research funding (Process No. APQ-028205.05/15) and the Research Support Center of the Federal Rural University of Pernambuco (CENAPESQ/UFRPE) for performing the chemiluminescent immunoassay.

\section{References}

ALLEN, M. S.; PIANTONI, P. Metabolic control of feed intake: implication for metabolic disease of fresh cows. Veterinary Clinics of North America: Food Animal Practice, London, v. 29, n. 1, p. 279-297, 2013. DOI: 10.1016/j.cvfa.2013.04.001

ALLISON, R. W. Avaliação laboratorial das proteínas do plasma e do soro sanguíneo. In: THRALL, M. A.; WEISER, G.; ALLISON, R. W.; CAMPBELL, T. W. Hematologia e bioquímica clínica veterinária. 2. ed. Rio de Janeiro: Guanabara Koogan, 2015a. cap. 29, p. 398411.

ALLISON, R. W. Avaliação laboratorial do pâncreas e metabolismo da glicose. In: THRALL, M. A.; WEISER, G.; ALLISON, R. W.; CAMPBELL, T. W. Hematologia e bioquímica clínica veterinária. 2. ed. Rio de Janeiro: Guanabara Koogan, 2015b. cap. 27, p. 367-380.

AL-QUDAH, K. M. Oxidant and antioxidant profile of hyperketonemic ewes affected by pregnancy toxemia. Veterinary Clinical Pathology, Madison, v. 40, n. 1, p. 60-65, 2011. DOI: 10.1111/j.1939-165X.2011.00284.x

ASRAT, M.; TADESSE, G. H.; GOUNDER, R. V.; NAGAPPAN, R. Prevalence and treatment of ketosis in dairy cows in and around Addis Ababa, Ethiopia. British Journal of Dairy Sciences, Taiwan, v. 3, n. 3, p. 26-30, 2013.

BALI, G.; HUSSAIN, K.; RAZZAQUE, W. A. A.; SHARMA, U.; BEIGH, S. A. Clinico-biochemical studies of ketosis in buffalo (Bubalus bubalis). Buffalo Bulletin, Bangkok, v. 35, n. 1, p. 27-32, 2016.

BALOGH, O.; SZEPES, O.; KOVACS, K.; KULCSAR, M.; REICZIGEL, J.; ALCAZAR, J. A.; KERESZTES, M.; FEBEL, H.; BARTYIK, J.; FEKETE, S. G. Y.; FSUS, L.; HUSZENICZA, G. Y. Interrelationships of growth hormone AluI polymorphismo, insulin resistance, milk production and reproductive performance in HolsteinFriesian cows. Veterinární Medicína, Prague, v. 53, n. 11, p. 604-616, 2008. DOI: 10.1016/j.livsci.2008.11.002

BASBUGAN, Y.; YÜKSEK, N.;ALTUG, N. Significance of homocysteine and cardiac markers in cattle with hypocalcemia. Turkish Journal of Veterinary and Animal Sciences, Ankara, v. 39, p. 699-704, 2015. DOI: 10.3906/ vet-1505-101

BISWAL, S.; NAYAK, D. C.; SARDAR, K. K. Prevalence of ketosis in dairy cows in milk shed areas of Odisha state, India. Veterinary World, Rajkot, v. 9, n. 11, p. 12421247, 2016. DOI: 10.14202/vetworld.2016.1242-1247

CÂMARA, A. C. L.; AFONSO, J. A. B.; COSTA, N. A.; MENDONÇA, C. L.; SOUZA, M. I. Primary abomasal impaction in 14 cattle from Pernambuco State, northeastern Brazil. Pesquisa Veterinária Brasileira, Seropédica, v. 29, n. 5, p. 387-394, 2009. DOI: 10.1590/ S0100-736X2009000500005

CÂMARA, A. C. L.; AFONSO, J. A. B.; COSTA, N. A.; MENDONÇA, C. L.; SOUZA, M. I.; BORGES, J. R. J. Risk factors, clinical and laboratorial findings and therapeutic evaluation in 36 cattle with abomasal displacement. Pesquisa Veterinária Brasileira, Seropédica, v. 30, n. 5, p. 453-464, 2010. DOI: 10.1590/ S0100-736X2010000500014.

CEBRA, C. K.; GARRY, F.; GETZY, D. M.; FETTMAN, M. J. Hepatic lipidosis in anorectic, lactating holstein cattle: a retrospective study of serum biochemical abnormalities. Journal of Veterinary Internal Medicine, Greenwood Village, v. 11, n. 4, p. 231-237, 1997. DOI: 10.1111/j.1939-1676.1997.tb00096.x

CHALMEH, A.; HAJIMOHAMMADI, A. Circulating metabolic hormones in different metabolic states of high producing Holstein dairy cows. Iranian Journal of Veterinary Medicine, Tehran, v. 10, n. 4, p. 277-284, 2016.

CHAPINAL, N.; CARSON, M.; DUFFIELD, T. F.; CAPEL, M.; GODDEN, S.; OVERTON, M.; SANTOS, J. E. P.; LEBLANC, S. J. The association of serum 
metabolites with clinical disease during the transition period. Journal of Dairy Science, Champaign, v. 94, n. 10, p. 4897-4903, 2011. DOI: 10.3168/jds.2010-4075

CONSTABLE, P. D.; HINCHCLIFF, K. W.; DONE, S. H.; GRÜNBERG, W. Veterinary medicine: a textbook of the diseases of cattle, horses, sheep, pigs, and goats. $11^{\text {th }}$ ed. St. Louis: Elsevier, 2017. 2358 p.

DAR, A. M.; MALIK, H. U.; SHAH, O. S.; BEIGH, S. A.; HUSSAIN, S. A.; HUSSAIN, T.; JAN, A.; AMIN, U.; NABI, S. U. Retrospective and prospective studies on prevalence of Bovine ketosis in Kashmir Valley. Journal of Entomology and Zoology Studies, Rohini, v. 5, n. 6, p. 1832-1835, 2017.

DIRKSEN, G.; GRÜNDER, H. D.; STÖBER, M. Rosenberger: exame clínico dos bovinos. 3. ed. Rio de Janeiro: Guanabara Koogan, 1993. 419 p.

DJOKOVIĆ, R.; CINCOVIĆ, M.; KURĆUBIĆ, V.; PETROVIĆ, M.; LALOVIĆ, M.; JAŠOVIĆ, B.; STANIMIROVIC, Z. Endocrine and metabolic status of dairy cows during transition period. Thai Journal of Veterinary Medicine, Taipei, v. 44, n. 1, p. 59-66, 2014.

DJOKOVIĆ, R.; DOSKOVIĆ, V.; CINCOVIĆ, M.; BELIĆ, B.; FRATRIĆ, N.; JAŠSOVIĆ, B.; LALOVIĆ, $M$. Estimation of insulin resistance in healthy and ketotic cows during an intravenous glucose tolerance test. Pakistan Veterinary Journal, Faisalabad, v. 37, n. 4, p. 387-392, 2017.

DJOKOVIĆ, R.; ŠAMANC, H.; ILIĆ, Z.; KURĆUBIĆ, $\mathrm{V}$. Blood glucose, insulin and inorganic phosphorus in healthy and ketotic dairy cows after intravenous infusion of glucose solution. Acta Veterinaria Brno, Brno, v. 78, n. 3, p. 449-453, 2009. DOI: 10.2754/avb200978030449

DRACKLEY, J. K.; DANN, H. M.; DOUGLAS, N.; GURETZKY, N. A. J.; LITHERLAND, N. B.; UNDERWOOD, J. P.; LOOR, J. J. Physiological and pathological adaptations in dairy cows that may increase susceptibility to periparturient diseases and disorders. Italian Journal of Animal Science, v. 4, n. 4, p. 323-344, 2005. DOI: $10.4081 /$ ijas.2005.323

DUFFIELD, T. F.; LISSEMORE, K. D.; MCBRIDE, B. W.; LESLIE, E. K. E. Impact of hyperketonemia in early lactation dairy cows on health and production. Journal of Dairy Science, Champaign, v. 92, n. 2, p. 571-580, 2009. DOI: $10.3168 /$ jds.2008-1507

EL-DEEB, W. M. Ketosis and associated oxidative stress in ruminants. Veterinary Science \& Technology, v. 6, n. 1, p. 114, 2015. DOI: 10.4172/2157-7579.1000e114

ELITOK, B.; SOLAK, M.; KABU, M.; ELITOK, O. M.; SOYLEMEZ, Z.; FISTIK, T. Clinical, haematological, serum biochemical and cytogenetic study in cows with primary ketosis. Pakistan Veterinary Journal, Faisalabad, v. 30, n. 3, p. 50-54, 2010.

FORSLUND, K. B.; LJUNGVALL, O. A.; JONES, E. B. Low cortisol levels in blood from dairy cows with ketosis: a field study. Acta Veterinaria Scandinavica, London, v. 52, n. 31, p. 1-6, 2010. DOI: 10.1186/17510147-52-31.

FOSTER, L. A. Clinical ketosis. Veterinary Clinics of North America: Food Animal Practice, London, v. 4, n. 2, p. 253-265, 1988.

GEREDE, D. M.; KOZLUCA, V.; ESENBOĞA, K.; AYDOĞAN, B. İ.; TUTAR, E. Markedly elevated troponin in diabetic ketoacidosis without acute coronary syndrome. Turkish Journal of Endocrinology and Metabolism, Turkey, v. 20, p. 58-60, 2016. DOI: 10.4274/ tjem.2997

GOFF, J. P. Calcium and magnesium disorders. Veterinary Clinics of North America: Food Animal Practice, London, v. 30, n. 2, p. 359-381, 2014. DOI: 10.1016/j. cvfa.2014.04.003

GONZÁLEZ, F. D.; MUIÑO, R.; PEREIRA, V.; CAMPOS, R.; BENEDITO, J. L. Relationship among blood indicators of lipomobilization and hepatic function during early lactation in high-yielding dairy cows. Journal of Veterinary Science, Seoul, v. 12, n. 3, p. 251255, 2011. DOI: 10.4142/jvs.2011.12.3.251

GORDON, J. L.; LEBLANC, S. J.; DUFFIELD, T. F. Ketosis treatment in lactating dairy cattle. Veterinary Clinics of North America: Food Animal Practice, London, v. 29, n. 2, p. 433-445, 2013. DOI: $10.1016 /$ j. cvfa.2013.03.001

HAYIRLI, A. The role of exogenous insulin in the complex of hepatic lipidosis and ketosis associated with insulin resistance phenomenon in postpartum dairy cattle. Veterinary Research Communications, v. 30, n. 7, p. 749-774, 2006. DOI: 10.1007/s11259-006-3320-6

HENZE，P.; BICKHARDT, K.; FUHRMANN, H.; SALLMANN, H. P. Spontaneous pregnancy toxaemia (Ketosis) in sheep and the role of insulin. Journal of Veterinary Medicine Series A, Berlin, v. 45, p. 255-266, 1998.

HOFFMANN, W. E.; SOLTER, P. F. Diagnostic enzymology of domestic animals. In: KANEKO, J. J.; HARVEY, J. W.; BRUSS, M. L. Clinical biochemistry of domestic animals. $6^{\text {th }}$ ed. San Diego: Academic Press, 2008. cap. 12, p. 351-378.

HOLTENIUS, P.; HOLTENIUS, K. A model to estimate insulin sensitivity in dairy cows. Acta Veterinaria Scandinavica, London, v. 49, n. 1, p. 29-31, 2007. DOI: 10.1186/1751-0147-49-29 
İSSİ, M.; GÜL, Y.; BAŞBUĞ, O. Evaluation of renal and hepatic functions in cattle with subclinical and clinical ketosis. Turkish Journal of Veterinary and Animal Sciences, Ankara, v. 40, n. 1, p. 47-52, 2016. DOI: 10.3906/vet-1505-16

JACOB, T.; PAKKIRI, M. Oxidative stress and the level of antioxidants in the condition of sub-clinical ketosis associated with the increased milk somatic cell count. International Journal of Livestock Research, v. 7, n. 5, p. 228-233, 2017. DOI:10.5455/ijlr.20170409094749

JAIN, S. K.; MCVIE, R.; BOCCHINI JUNIOR, J. A. Hyperketonemia (ketosis), oxidative stress and type 1 diabetes. Pathophysiology, v. 13, p. 163-170, 2006. DOI: 10.1016/j.pathophys.2006.05.005

KANEKO, J. J. Carbohydrate metabolism and its diseases. In: KANEKO, J. T.; HARVEY, S. W.; BRUSS, M. L. Clinical biochemistry of domestic animals. $6^{\text {th }}$ ed. San Diego: Academic Press, 2008. cap. 3, p. 45-80.

KARIMI, N.; MOHRI, M.; ALDIN, H.; AZIZZADEH, M.; HEIDARPOUR, M. Relationships between trace elements, oxidative stress and subclinical ketosis during transition period in dairy cows. Iranian Journal of Veterinary Science and Technology, Mashhad, v. 7, n. 2, p. 46-56, 2015. DOI: $10.22067 /$ veterinary.v7i2.45798

KERESTES, M.; FAIGL， V.; KULCSÁR， M.; BALOGH, O.; FÖLDI, J.; FÉBEL, H.; CHILLIARD, Y.; HUSZENICZA, G. Periparturient insulin secretion and whole-body insulin responsiveness in dairy cows showing various forms of ketone pattern with or without puerperal metritis. Domestic Animal Endocrinology, v. 37, n. 4, p. 250-261, 2009. DOI:10.1016/j.domaniend.2009.07.003

KOSTER, J. D.; OPSOMER, G. Insulin resistance in dairy cows. Veterinary Clinics of North America: Food Animal Practice, London, v. 29, n. 1, p. 299-322, 2013. DOI: 10.1016/j.cvfa.2013.04.002

KUMAR, A.; SINDHU, N.; KUMAR, P.; KUMAR, T.; CHARAYA, G.; SURBHI; JAIN, V. K.; SRIDHAR. Incidence and clinical vital parameters in primary ketosis of Murrah buffaloes. Veterinary World, Rajkot, v. 8, n. 9, p. 1083-1087, 2015. DOI: $10.14202 /$ vetworld.2015.1083-108

LEAN, I. J. Non-infectious diseases: ketosis. Bovine Research Australasia, Australia, v. 2, p. 815-823, 2002.

LIMA, E. S.; ABDALLA, D. S. P. Peroxidação lipídica: mecanismos e avaliação em amostras biológicas. Brazilian Journal of Pharmaceutical Sciences, São Paulo, v. 37, n. 3, p. 293-303, 2001.

LITTLE, T. M.; HILLS, F. J. Agricultural experimentation: design and analysis. New York: John Wiley \& Sons, 1978. 350 p.
MARUTSOVA, V.; MARUTSOV, P. Body condition scoring and changes in some blood biochemical parameters in cows with subclinical and clinical ketosis. International Journal of Advanced Research, v. 4, n. 11, p. 405-412, 2016. DOI: 10.21474/IJAR01/2098

MCART, J. A. A.; NYDAM, D. V.; OETZEL, G. R.; OVERTON, T. R.; OSPINA, P. A. Elevated non-esterified fatty acids and $\beta$-hydroxybutyrate and their association with transition dairy cow performance. The Veterinary Journal, Londres, v. 198, n. 3, p. 560-570, 2013. DOI: 10.21474/IJAR01/2098

NASCIMENTO, P. M. Impacto da administração das vitaminas $D$ e $E$ na sensibilidades insulínica, metabolismo oxidativo e aspectos da imunidade de ovelhas no periodo periparto. 2018. Tese (Doutorado em Ciência) - Faculdade de Medicina Veterinária e Zootecnia, Universidade de São Paulo, São Paulo.

OETZEL, G. R. Herd-level ketosis - diagnosis and risk factors. In: PRECONFERENCE SEMINAR 7C: DAIRY HERD PROBLEM INVESTIGATION STRATEGIES: TRANSITION COW TROUBLESHOOTING, ANNUAL CONFERENCE, 40., 2007, Vancouver. Proceeding... Vancouver: University of Wisconsin, 2007. p. 67-91. Available at: https://www.vetmed.wisc. edu/dms/fapm/fapmtools/2nutr/ketosis.pdf. Accessed at: 20 jan. 2019.

ORMAZABAL, V.; NAIR, S.; ELFEKY, O.; AGUAYO, C.; SALOMON, C.; ZUNIGA, F. A. Association between insulin resistance and the development of cardiovascular disease. Cardiovasc Diabetology, v. 17, n. 122, p. 4-14, 2018. DOI: 10.1186/s12933-018-0762-4

RASMUSSENT, L. K.; NIELSEN, B. L.; PRYCE, J. E.; MOTTRAM, T. T.; VEERKAMP, R. F. Risk factors associated with the incidence of ketosis in dairy cows. Animal Science, Liverpool, v. 68, p. 379-386, 1999. DOI: 10.1017/S1357729800050372

REDDY, B. S.; REDDY, B. S. S.; REDDY, Y. V. P.; VENNKATASIVAKUMAR, R. Nervous form of ketosis in cows and its treatment. International Journal of Biological Research, Ras Al Khaimah, v. 2, n. 2, p. 43144, 2014. DOI: 10.14419/ijbr.v2i2.3591

REIS, J. F.; MADUREIRA, K. M.; SILVA, C. P. C.; BALDACIM, V. P. A.; FAGLIARI, J. J.; GOMES, V. Serum protein profile of Holstein cows during the transition period. Arquivo Brasileiro de Medicina Veterinária e Zootecnia, Belo Horizonte, v. 68, n. 3, p. 587-595, 2016. DOI: 10.1590/1678-4162-8772

SAHINDURAN, S.; SEZER, K.; BUYUKOGLU, T.; ALBAY, M. K.; KARAKURUMM, M. C. Evaluation of some haematological and biochemical parameters before 
and after treatment in cows with ketosis and comparison of different treatment methods. Journal of Animal and Veterinary Advances, Dubai, v. 9, n. 2, p. 266-271, 2010. DOI: $10.3923 /$ javaa.2010.266.271

SANTOS, F. C. O.; MENDONÇA, C. L.; SILVA FILHO, A. P.; CARVALHO, C. C. D.; SOARES, P. C.; AFONSO, J. A. B. Biochemical and hormonal indicators of natural cases of pregnancy toxaemia of in sheep. Pesquisa Veterinária Brasileira, Seropédica, v. 31, n. 11, p. 974980, 2011. DOI: 10.1590/S0100-736X2011001100006

SATO, H. Increased blood concentration of isopropanol in ketotic dairy cows and isopropanol production from acetone in the rumen. Animal Science Journal, v. 80 , n. 4 , p. $381-386,2009$. DOI: $10.1111 /$ j.17400929.2009.00649.x

SAUT, J. P. E.; MIYASHIRO, S. I.; RAIMONDO, R. F. S.; BIRGEL JUNIOR, E. H. Influência do período pós-parto no proteinograma de vacas holandesas, obtido através da técnica de eletroforese em gel de poliacrilamida. Ciência Animal Brasileira, Goiânia, p. 244-249, 2009. Suplemento1.

SEIFI, H. A.; LEBLANC, S. J.; LESLIE, K. E.; DUFFIELD, T. F. Metabolic predictors of post-partum disease and culling risk in dairy cattle. The Veterinary Journal, Londres, v. 188, n. 2, p. 216-220, 2011. DOI: doi:10.1016/j.tvj1.2010.04.007

ŞENTÜRK, S.; CIHAN, H.; MECITOĞLU, Z.; ÇATIK, S.; DEMIR AKGÜL, G.; KASAP, S.; TOPAL, O. Prevalence of ketosis in dairy herds in Marmara, Aegean and Mediterranean regions of Turkey. Ankara Universitesi Veteriner Fakultesi Dergisi, Ankara, v. 63, n. 3, p. 283-288, 2016. DOI: 10.1501/Vetfak_0000002741

SHIN, E. K.; JEONG, J. K.; CHOI, I. S.; KANG, H. G. Theriogenology relationships among ketosis, serum metabolites, body condition, and reproductive outcomes in dairy cows. Theriogenology, v. 84, n. 2, p. 252-260, 2015. DOI: 10.1016/j.theriogenology.2015.03.014

SILVA FILHO, A. P.; AFONSO, J. A. B.; SOUZA, J. C. A.; DANTAS, A. C.; COSTA, N. A.; MENDONÇA, C. L. Achados clínicos de bovinos com úlcera de abomaso. Veterinária e Zootecnia, Botucatu, v. 19, n. 2, p. 196-206, 2012.

SIMONOV, M. R.; VLIZLO, V. V. Some indicators of protein metabolism in blood of cows under ketosis. The Animal Biology, Lviv, v. 15, n. 3, p. 120-124, 2013. DOI: 10.15407/animbiol15.03.120

SORDILLO, L. M.; WILLIAM, R. Significance of metabolic stress, lipid mobilization, and inflammation on transition cow disorders. Veterinary Clinics of North America: Food Animal Practice, London, v. 29, n. 1, p.
267-278, 2013. DOI: 10.1016/j.cvfa.2013.03.002

SORONDO, M. L.; CIRIO, A. Evaluation of the serum fructosamine test to monitor plasma glucose concentration in the transition dairy cow. Journal of Dairy Research, v. 76, n. 2, p. 173-178, 2009. DOI: 10.1017/S0022029908003750

SOUTO, R. J. C.; AFONSO, J. A. B.; MENDONÇA, C. L.; CARVAlHO, C. C. D.; SILVA FILHO, A. P.; CAJUEIRO, J. F. P.; LIMA, E. H. F.; SOARES, P. C. Biochemical, electrolytic and hormonal findings in goats affected with pregnancy toxemia. Pesquisa Veterinária Brasileira, Seropédica, v. 33, n. 10, p. 1174-1182, 2013. DOI: $10.1590 / \mathrm{s} 0100-736 \times 2013001000002$

SOUZA, L. M.; MENDONÇA, C. L.; ASSIS, R. N.; NUNES, D.; OLIVEIRA FILHO, E. F.; SOUTO, R. J. C.; SOARES, P. C.; AFONSO, J. A. B. Use of troponin $\mathrm{I}$ and CK-MB as heart biomarkers in sheep affected by pregnancy toxemia. Medicina Veterinária (UFRPE), Recife, v. 12, p. 143-143, 2018. Supplement 1.

STENGÄRDE, L.; HOLTENIUS, K.; EMANUELSON, U.; HULTGREN, J.; NISKANEN, R.; TRÅVÉN, M. Blood parameters in Swedish dairy herds with high or low incidence of displaced abomasum or ketosis. The Veterinary Journal, Londres, v. 190, n. 1, p. 124-130, 2011. DOI: $10.1016 /$ j.tvj1.2010.09.011

SUTHAR, V. S.; CANELAS-RAPOSO, J.; DENIZ, A.; HEUWIESER, W. Prevalence of subclinical ketosis and relationships with postpartum diseases in European dairy cows. Journal of Dairy Science, Champaign, v. 96, n. 5, p. 1-14, 2013. DOI: $10.3168 / j d s .2012-6035$

THARWAT, M.; AL-SOBAYIL, F.; AL-SOBAYIL, $\mathrm{K}$. The cardiac biomarkers troponin I and CK-MB in nonpregnant and pregnant goats, goats with normal birth, goats with prolonged birth, and goats with pregnancy toxemia. Theriogenology, v. 78, p. 1500-1507, 2012. DOI: $10.1016 / j$.theriogenology.2012.06.013

TONTIS, A.; ZWAHLEN, R. Pregnancy toxemia of small ruminants with special reference to pathomorphology. Tierarztl Praxis, v. 15, n. 1, p. 25-29, 1987.

UPADHYAY, S. R.; SHARMA, N.; PANDEY, V. Nervous ketosis in buffalo - a case report. Intas Polivet, Ahmedabad, v. 8, n. 2, p. 404-406, 2007.

VAJA, V. B.; MANVAR, N. B.; DODIYA, P. G.; PATEL, J. S.; JOSEPH, J. P.; PATEL, B. R. Clinico-therapeutic management of ketosis in gir cattle. International Journal of Science, Environment, v. 5, n. 5, p. 3429-3434, 2016.

VANHOLDER, T.; PAPEN, J.; BEMERS, R.; VERTENTEN, G.; BERGE, A. C. B. Risk factors or subclinical and clinical ketosis and association with 
production parameters in dairy cows in the Netherlands. Journal of Dairy Science, Champaign, v. 98, n. 2, p. 880888, 2015. DOI: 1 0.3168/jds.2014-8362

VARGA, A.; ANGELOS, J. A.; GRAHAM, T. W.; CHIGERWE, M. Preliminary investigation of cardiac troponin I concentration in cows with common production diseases. Journal of Veterinary Internal Medicine, Greenwood Village, v. 27, p. 1613-1621, 2013. DOI: $10.1111 /$ jvim. 12213

WOOTTON, P. Nervous ketosis. Canadian Veterinary Journal, Guelph, v. 33, p. 194-194, 1992.
XU, C.; SHU, S.; XIA, C.; WANG, B.; ZHANG, H. Y.; JUN, B. Investigation on the relationship of insulin resistance and ketosis in dairy cows. Journal of Veterinary Science \& Technology, v. 5, n. 2, p. 2-5, 2014. DOI: $10.4172 / 2157-7579.1000162$

YAMEOGO, N.; OUEDRAOGO, G. A.; KANYANDEKWE, C.; SAWADOGO, G. J. Relationship between ketosis and dairy cows' blood metabolites in intensive production farms of the periurban area of Dakar. Tropical Animal Health and Production, Edinburgh, v. 40, p. 483-490, 2008. DOI: 10.1007/s11250-007-9124-Z 
